\section{Structure and dynamics of a beech forest in a fully protected area in the northern Apennines (Sasso Fratino, Italy)}

\author{
Bianchi L ${ }^{(1)}$, Bottacci $A^{(2)}$, Calamini G ${ }^{(1)}$, Maltoni $A^{(1)}$, Mariotti B ${ }^{(1)}$, \\ Quilghini $G^{(3)}$, Salbitano $F^{(1)}$, Tani $A^{(1)}$, Zoccola $A^{(2)}$, Paci $M^{(1)}$
}

Sasso Fratino Nature Reserve (National Park of Casentino Forests, northern Apennines) is a quite rare example of natural Apennine forest. The Reserve was established in 1959, aiming to protect a forest, although not a virgin one, low-intensively disturbed in the past by comparison with other neighbouring stands. Causes of such a low disturbance are the very limited accessibility of the area due to the very steep slopes characterising the site morphology, as well as historical features. The forest is a pure beech stand from $1250 \mathrm{~m}$ a.s.l. upwards, below this altitude is a mixed beech and silver fir forest. The study focuses on the understanding of the processes driving the evolution of the forest in the absence of human activities. To achieve this goal, 9 permanent, long-term research plots were established at different altitudes, in order to investigate on forest dynamics and regeneration processes. Simplified (single-layer) stand structures are more frequent where canopy gaps are absent. Twolayered structures are the result of the occurrence of canopy gaps, which allow the settlement, and subsequently the establishment, of a lower regeneration layer. Where the gap dimensions allow canopy closure, this kind of structure persists. When the gaps are quite large, the regeneration layer reaches the top layer and the structure stand tends, once more, toward a single-layer. Multilayered structures are extremely rare at plot level and become evident only at a wider scale. Our surveys indicate also a high variability of tree diameter distribution patterns in the forest stands. Such variability could be strictly related to the heterogeneity of site characteristics as well as to the effects of disturbance factors (both natural and anthropic). Concerning altitude, we observed an increase both of site index (dominant height) and species diversity in the regeneration layer, moving from higher $(1500 \mathrm{~m})$ to lower $(900$ $\mathrm{m}$ ) altitudes. As a whole, our observations show that the dynamics of forest vegetation in the reserve is mostly affected by the interruption of tree canopy continuity. This implies substantial local variations of PAR in space and in time, which determine favourable ecological conditions for: (a) survival and growth of beech seedlings, or release of advanced beech regeneration; and (b) release of advanced silver fir regeneration (fir, more shade tolerant than beech, regenerates mainly in locations and conditions where the broadleaf saplings cannot survive for lack of light). The knowledge of the mechanisms of vegetation dynamics in the Reserve can be used to form the basis of close-to-nature silvicultural choices in similar stands in order to increase functionality and stability. Periodical monitoring of RNI will allow the investigation of the evolutionary trends of the forest stands.

Keywords: Old growth forest, Forest stand dynamics, Beech - Silver fir mixed stand, Forest management

\section{Introduction}

Forest stand structure is the result of the environmental history of a phytocoenosis and includes anthropic influences. The study of the disturbances and structural dynamics of forest ecosystems that have not been influenced by human activity is one of the most effective approaches to describe and understand stand dynamics for the application of close-to-nature silviculture (Oliver \& Larson 1996, Gamborg \& Larsen 2003). The adjustments of forest structure are responses to complex relationships among individuals, populations and the environment: such relationships are realized through competitive processes and biovolume control (Townsend et al. 2003). Over time, these interrelationships are expressed in spatial arrangements.

Fully-protected, natural forest reserves play the role of living laboratories, where the processes responsible for forest dynamics can be analysed and monitored over time. Studies
(1) DEISTAF, University of Florence (FI Italy); (2) CFS, UTB Pratovecchio (AR Italy); (3) CFS, UTB Follonica (GR - Italy)

@ Livio Bianchi (livio.bianchi@unifi.it)

Received: Nov 15, 2010 - Accepted: Mar 03, 2011

Citation: Bianchi L, Bottacci A, Calamini G, Maltoni A, Mariotti B, Quilghini G, Salbitano F, Tani A, Zoccola A, Paci M, 2011.

Structure and dynamics of a beech forest in a fully protected area in the northern Apennines (Sasso Fratino, Italy). iForest 4: 136-144 [online 2011-06-01] URL: http://www.sisef.it/iforest/show.php? id $=564$

on the structure and dynamics of beech-dominated woods are frequent in the central and northern areas of the natural range of Fagus sylvatica (Leibundgut 1982, Koop 1989, Oldeman 1990, Emborg 1998, Emborg et al. 2000, Ritter et al. 2005); however, they have rarely been conducted in southern areas (A.A.V.V. 1999) and, particularly, in the Apennine woods.

The beech-dominated Apennine woods cover an area of roughly 600000 hectares (INFC 2008) and more than 50\% are coppices. In these stands, the application of close-to-nature silviculture meets increasing needs for both ecological stability and multifunctional utilization (A.A.V.V. 2004, Schütz 2006).

A number of factors affect the present physiognomy (in terms of spatial structure and composition) of the Italian beech woods. Foremost, in its ecological optimum, beech is the most competitive species and dominates the growing space; however, in less than optimum conditions for Fagus sylvatica, forestry practices or anthropogenic disturbances (grazing, fires, etc.) have often strengthened the dominance of beech (Paci \& Salbitano 1998). By contrast, decreasing anthropic pressure has often caused the evolution towards mixed stands In addition, in mixed woods, where silver fir is the species most frequently associated with beech, several aspects have likely influenced stand structure, including: a) past coppicing has promoted beech; b) silver fir trees were preferred in past harvesting, reducing beech regeneration chances; and c) in other cases, silver fir was favoured for economical reasons and beech was gradually eliminated. Silver fir stands were managed as even-aged pure stands, using clearcutting and artificial regeneration.

According to the first studies conducted in the Reserve of Sasso Fratino (RNI), forest stands were considered similar to a virgin forest (Nardi Berti 1972). The general his- 
tory of the forests of the area has been fully described by Gabbrielli \& Sottesoldi 1977, Gabbrielli (1978), Padula (1983) and Bottacci (2009). Since 1914, the forest has been managed by the State Forest Service and very little logging has been conducted. The few harvests that have occurred have been distributed so that the impact was minimized. The core of the Reserve was established in 1959 over an area of 113 hectares on the basis of an internal administrative act by the Azienda di Stato per le Foreste Demaniali, the State Forest Agency, and was subsequently recognized by a State D.M (Ministerial Decree) dated July 26, 1971 Sasso Fratino was the first fully protected nature reserve in Italy and today covers an area of 764 hectares.

The most recent timber harvest in the forest (reconstructed using the management plan for the years 1934-1943) was conducted by the State Forestry Agency. The research area is described as "dense and mature beech and fir mixed stands with the presence of abundant regeneration on almost the whole area mainly in the upper sector where the tree density is lower and the distribution even". The latest documented timber harvest was in 1936 and consisted of $325 \mathrm{~m}^{3}$ of timber $(80$ beech logs for a total of $42 \mathrm{~m}^{3}$ and 608 silver fir trunks for a total of $283 \mathrm{~m}^{3}$ ) and 22.8 steres of beech fuelwood (15 charcoal areas homogeneously distributed in altitude were pointed out by Nardi Berti 1972). Considering the low level of past exploitation, we can assume that logging was concentrated in the most accessible sites, and distributed in areas where it was possible to minimize the impact on the land, as was required by the State Forestry Agency. Furthermore, considering the easier accessibility of the upper areas due to the proximity of roads, these harvests would have likely occurred in the middle and upper parts (above $1250 \mathrm{~m}$ ) of the forest.

At present, because of the lack of anthropic influences over the last seven decades, Sasso Fratino is considered as one of the best examples of old growth and natural forests in Italy.

Oldeman (1990) proposed an analysis of forest ecosystems aimed to highlight oldgrowth (and, therefore, natural) characteristics through the study of forest structure The "silvomosaic" of an old-growth forest shows specific characteristics if compared with managed forests, the most important being the concurrent presence of all of the phases of the forest cycle. According to this model, the more of the different phases that are present contemporaneously in the forest, the closer the forest is to natural conditions. This approach involves a simplification of the study of forest ecosystem complexity, but it can be a useful interpretative key from a silvicultural point of view.
In the framework of Italian forests, RNI represents a living laboratory of inestimable value because it shows the results of natural processes working without human influence over the last seventy years. Research in the RNI has been carried out for decades (Nardi Berti 1972, Paci \& Salbitano 1998) with ecological and management goals. In this sense, the aim of the current research is to highlight the main factors which influence the successional processes in the RNI. The knowledge of the mechanisms of vegetation dynamics in the RNI can be used to form the basis of close-to-nature silvicultural choices in similar stands in order to increase functionality and stability. To achieve this goal, permanent, long-term research plots were established.

\section{Environment}

The Natural Integral Reserve of Sasso Fratino is located in Central Italy in the northern portion of the Tuscany and Romagna Apennines (latitude $43^{\circ} 11^{\prime} \mathrm{N}$; longitude $\left.11^{\circ} 47^{\prime} \mathrm{E}\right)$. The reserve covers an area of roughly 780 hectares. The elevation ranges between 650 and $1520 \mathrm{~m}$ a.s.l. Morphology is irregular, with an average slope higher than $65 \%$ and often $100 \%$, and rock crags are frequent.

The bedrock of the area is the Miocene sandstone marl series (Romagnola facies: bands of stone rock alternating with layers of marl shale). The soils were classified as inceptisols (grey-brown soils, fairly leached: Sanesi 1962)

The average annual temperature is $9^{\circ} \mathrm{C}$ and the annual temperature excursion is $16.4^{\circ} \mathrm{C}$. Average annual rainfall is 1750 $\mathrm{mm}, 255 \mathrm{~mm}$ of which falls in the summer. Atmospheric moisture is high throughout the year and foggy days (48 days in average) are quite frequent during the growing season. Snow cover lasts about 3 months from December to February. The prevailing winds blow from SW and NE and can be blustery along the ridges. Based on the RivasMartinez classification (Rivas-Martínez 2005), the bioclimate is part of the "ocean temperate, subtemperate hyperhumid belt". The vegetation type belongs to "mountain belt" Fagus and Fagus-Abies series sensu Ozenda (1985).

The study was carried out in the original RNI nucleus (about 113 hectares), which has been under full protection since 1959 . The study area stretches from Poggio Scali (1520 $\mathrm{m}$ a.s.l.) to the confluence of the Acqua Fredda and Sasso Fratino (900 m a.s.1.) streams.

\section{Materials and Methods}

\section{Data collection}

In order to sample all of the RNI stands, a general survey of the present physiognomy of the stands was carried out over the entire study area. After the large-scale survey, two different aspects were investigated.

First, a survey of the representative flora of the RNI was conducted in 9 plots located at different altitudes. Each plot was named with the prefix SF and numbered from 1 to 9 in relation to decreasing altitude. Data were collected 5 times for each plot during the growing season (May 6, May 17, June 3, June 22, and August 2, 2005). The plots were circular with a $10 \mathrm{~m}$ radius. The species were determined using the reference of the Flora d'Italia (Pignatti 1982). Each species was assessed on the abundance-dominance index, according to the Braun-Blanquet's scale (Braun-Blanquet 1932), modified by Pignatti (1976). The biological form (sensu Raunkiaer 1934) and the chorological element (sensu Pignatti 1982) were also classified.

Five out of the 9 plots were selected for this survey as the most representative of the stand physiognomy observed within the entire study area. A $1000 \mathrm{~m}^{2}$ transect plot $(50 \mathrm{x}$ $20 \mathrm{~m}$, subdivided into four $250 \mathrm{~m}^{2}-20 \mathrm{x} 10$ $\mathrm{m}$ sub-plots) was permanently outlined. The following parameters were recorded for each woody plant higher than $150 \mathrm{~cm}$ : species, position, diameter (d), total height (h), crown depth and crown ground projection (according to four perpendicular radius lines). In a $300 \mathrm{~m}^{2}$ transect plot $(50 \times 6 \mathrm{~m}$, further subdivided into 6 sections - $10 \times 6 \mathrm{~m}$ across the medium line of the former plots), species, position and height were recorded for each individual woody plant lower than $150 \mathrm{~cm}$. In order to obtain indirect data about the canopy cover, the relative irradiance (I.R.) within the PAR range was measured using two ceptometers (Sunscan Canopy Analysis System, AT Delta-T Devices, Ltd). During July and August 2005, two measurements, one under canopy cover and the other in open space (as control) were taken simultaneously during mid-daylight hours, precisely between 11:30 and 1:30 p.m. (standard time), in sunny conditions.

\section{Data processing}

Data were processed in order to summarize the main characteristics of the stand structure: the number of plants and basal area per hectare $\left(\mathrm{n} \mathrm{ha}^{-1}, \mathrm{G} \mathrm{ha}^{-1}\right)$, average tree height of the individuals belonging to the upper layer $\left(\mathrm{H}_{\mathrm{m}}\right)$, and frequency of trees in terms of diameter $(10 \mathrm{~cm}$ interval) and height $(5 \mathrm{~m}$ interval) class. In order to describe the spatial structures, 3 canopy layers were identified: the lower layer (regeneration layer, up to $3 \mathrm{~m}$ height), the upper layer (composed of individuals of the two top height classes), and the medium layer, including the remaining trees. The spatial structure of the stand was described on the basis of the reciprocal position of the trees in the frame of single tree- 
clusters along the stand profile.

The average density of the individuals in the natural regeneration layer was calculated for each section, while the diversity level was evaluated applying the Shannon index (HS). Concerning the floristic investigations, the biological spectrum was determined on the basis of the frequency of biological forms. Furthermore, the Ellenberg's ecological indices (Ellenberg 1988) were assigned to each species. The indices were partially modified to consider the actual variability of ecotopes. These indices highlight the ecological requirements of each species as compared to key factors such as light, temperature, continentality, humidity, soil acidity and nitrogen availability. Data processing helped to determine the general floristic lists, the number of species in each area, and the biological and chorological spectra; the results have been arranged on a phytosociological basis as well. The nine sample plots were also compared with the Jacquard's diversity index, considering the species present in each area according to the formula (eqn. 1):

$$
c /(a+b-c)
$$

where $a$ is the species in the first area, $b$ is the species in the second area, and $c$ is the species common to both areas. The similarity in the floristic composition of the plots was analysed by applying this index in a pairwise matrix of plots: the similarity between two plots increases from 0 (total dissimilarity) to 1 (overlapping).

The Kolomogorov-Smirnov (KS) and Weibull function (Wf) were used to evaluate and compare the distribution of diameters, in particular comparing the $\mathrm{C}$ form parameter of this function: if $\mathrm{C}<1$, then $\mathrm{J}$ reversed function; if $1<3.6$, then the mound bel shaped function was positively skewed; if $\mathrm{C}$ $\approx 3.6$ then there was a normal distribution (Bailey \& Dell 1973). Chi-square test was used to evaluate the per-layer distribution of plants. Finally ANOVA and Duncan posthoc tests were used to compare the average HS and I.R. values among the average number of the individuals in the natural regeneration layer.

\section{Results}

\section{General description of the research} area

Nardi Berti (1972) described the forest as a pure beech stand from $1250 \mathrm{~m}$ a.s.l. upwards. Below this altitude the RNI was described as mixed beech and silver fir forest. The mixture patterns were characterized both from individual and small groups of silver fir trees. The author points out that the forest structure tended to be even-aged and single layered at higher altitudes and uneven-aged and multi-layered in the lower section. Fur- thermore, it was emphasized that the frequency of dead trees was very low and mainly involved smaller plants.

According to our observations, the present situation is very similar to the one described above: beech is the dominant species over the entire area in terms both individual trees and biomass. At higher altitudes, where the slope is steeper, the soil is shallower and the wind more violent (especially in proximity to the ridges), the forest stand structure is rather similar to an aged coppice. The most frequent canopy profile is double-layered, consisting of an upper layer $(18 \mathrm{~m}<\mathrm{h}<24$ $\mathrm{m})$ where big trees were present, mostly beech $(\mathrm{D}>60 \mathrm{~cm})$ with a few scattered sycamores, in an even distribution. The canopy cover is discontinuous. Individuals of beech, sycomore maple, European hornbeam and, less frequently, mountain ash are present in the lower layer $(\mathrm{h}<3 \mathrm{~m})$. The tree space distribution is irregular and the structure is similar to a former coppice woodland.

At lower altitudes, the steepness of the slope decreases, soil thickness increases and wind influence is less noticeable. The stands show a physiognomy of mature and welldeveloped beech forests. The spatial structures vary according to former harvesting and, locally, to the action of natural abiotic factors. The canopy gaps are due to the collapse of one or a few plants. The only exception is a 1.5 hectare area located near the eastern border, where a landslide completely removed the forest stand in 1982. The area was colonized by Ostrya carpinifolia.

In canopy gaps, natural regeneration of beech, and less frequently sycomore maple, European ash and silver fir, is observed. In the smaller gaps, the edge trees tend to expand the crown to fill the available space: this process created a double-layered structure where beech regeneration shows symptoms of overshading. Where the canopy gaps are wider, progressive establishment and growth of natural regeneration has been observed: the spatial structure is doublelayered, but in this case, evolves quite rapidly to a one-layered, because of the fast growth of the individuals in the regeneration layer.

Tab. 1 - Biological spectrum, separately for plot and total (\%). (MP): macrofanerofite; (NP): nanofanerofite; $(\mathrm{Ch})$ : camefite; $(\mathrm{H})$ : hemicriptofite; $(\mathrm{G})$ : neofite; $(\mathrm{T})$ : terofite (Raunkiaer 1934).

\begin{tabular}{|c|c|c|c|c|c|c|c|c|c|c|}
\hline \multirow{3}{*}{ Form } & \multicolumn{9}{|c|}{ Plot } & \multirow{2}{*}{ Tot } \\
\hline & 1 & 2 & 3 & 4 & 5 & 6 & 7 & 8 & 9 & \\
\hline & $\%$ & $\%$ & $\%$ & $\%$ & $\%$ & $\%$ & $\%$ & $\%$ & $\%$ & $\%$ \\
\hline MP & 8.00 & 3.77 & 6.06 & 9.09 & 18.52 & 10.87 & 12.77 & 10.00 & 14.29 & 9.26 \\
\hline NP & 0.00 & 0.00 & 0.00 & 0.00 & 0.00 & 4.35 & 2.13 & 2.50 & 4.76 & 1.85 \\
\hline $\mathrm{Ch}$ & 4.00 & 1.89 & 0.00 & 0.00 & 0.00 & 0.00 & 0.00 & 2.50 & 2.38 & 0.93 \\
\hline $\mathrm{H}$ & 36.00 & 52.83 & 33.33 & 42.42 & 48.15 & 45.65 & 44.68 & 40.00 & 45.24 & 46.30 \\
\hline G & 36.00 & 32.08 & 54.55 & 39.39 & 29.63 & 28.26 & 31.91 & 35.00 & 26.19 & 36.11 \\
\hline $\mathrm{T}$ & 16.00 & 9.43 & 6.06 & 9.09 & 3.70 & 10.87 & 8.51 & 10.00 & 7.14 & 5.56 \\
\hline Total & 100 & 100 & 100 & 100 & 100 & 100 & 100 & 100 & 100 & 100 \\
\hline
\end{tabular}

The stands without canopy gaps exhibit a single layer structure. Beech trees $(\mathrm{H}>30$ $\mathrm{m})$ are evenly distributed, sometimes alternating with single trees or small groups of sycamore and silver fir. The canopy cover is almost complete. At altitudes below $1300 \mathrm{~m}$, and more frequently below $1200 \mathrm{~m}$ a.s.l., small groups or isolated individual silver fir and European yew (sporadic) trees, lower than $3 \mathrm{~m}$, could be observed. Below $950 \mathrm{~m}$ a.s.l., planted silver fir stands are more frehas been observed under the silver fir canopy.

\section{Floristic aspects}

Due to the objectives of the study, the floristic and phytosociological aspects should be considered only as a completion of the general description of the forest research area. The floristic check list (Appendix 1) shows 108 species belonging to 88 genus and 47 families. The most represented families were Compositae (10 species), Liliaceae (9 species), Cruciferae (8 species), and Gramineae ( 8 species). The highest number of species has been found in the SF2 plot (54 species), and the lowest number in SF1 (25 species). In SF2, the diversity of micro-habitat related to the presence of rocky outcrops and canopy openings, contributes to the floristic richness, as was found by Hofmann 1965.

Species typical of beech forests, such as Dryopteris filis-mas, Acer pseudoplatanus, Galium odoratum, Senecio nemorensis and Cardamine bulbifera, are present in all areas. The thermophytes such as Daphne laureola and Stellaria media are present only at the lower altitudes (SF6, SF7, SF8, and SF9).

Frequency analysis of the biological forms (Tab. 1) indicates the prevailing recurrence of the Hemicryptophytes, which are best adapted to lower temperatures. Therophytes, which are adapted to warmer climates in open spaces and to shallow or immature soils, are scarcely represented in any of the areas, excluding SF1 (the area located in proximity to the upper forest line). Eurasian species, typical of cold climates, are comquent. Broadleaf regeneration, mainly beech, 
Tab. 2 - Number of trees and basal area $(\mathrm{G} / \mathrm{ha})$, separately for plot and tree species (beech and other species).

\begin{tabular}{lcccccc}
\hline ADS & \multicolumn{3}{c}{$\mathbf{n / h a}$} & & \multicolumn{3}{c}{ G/ha } \\
\cline { 2 - 7 } & Beech & $\begin{array}{c}\text { Other } \\
\text { species }\end{array}$ & Total & Beech & $\begin{array}{c}\text { Other } \\
\text { species }\end{array}$ & Total \\
\hline SF1 & 660 & 110 & 770 & 41.3 & 9.1 & 50.5 \\
SF3 & 360 & - & 360 & 50.5 & - & 50.5 \\
SF4 & 1330 & 40 & 1370 & 36.7 & 6.3 & 42.9 \\
SF5 & 910 & - & 910 & 43.8 & - & 43.8 \\
SF8 & 80 & 60 & 140 & 43.9 & 6.4 & 50.3 \\
\hline
\end{tabular}

monly distributed in all areas. Orophytes are well represented in plots SF1, SF3, SF4, SF5 and less frequent in SF8, indicating that this plot experienced less severe climatic conditions. Cosmopolitan species are well represented all over the study area. Endemic species are absent in plots SF4 and SF5, rare in SF1, and fairly abundant in SF8. Euromediterranean species are present only in plots SF2 and SF7; because of the mountain climate of the RNI, these species only colonize the rocky outcrops and the stands where the canopy cover is rather discontinuous. Exotic species are absent as a consequence of low anthropic impact and long standing isolation from human settlements and activities.

The Ellenberg's indices analysis show the absence of light sensitive species (values: 89 ). The frequency of light insensitive species is very low $(<10 \%)$ as well. In all plots, species characteristic of the high mountain environments (value 1) are present, and by contrast, warm-sensitive species (values 8-9) are absent. Species indicating intermediate mountain temperatures (value 5) are the most frequent. The percentage of species adapted to moderately cold climates (value 3) decreases along the elevation gradient from plot SF1 to SF9; these species dominate the floristic composition of SF1 and $\mathrm{SF} 2$. The frequency of temperature insensitive species is very high, although it decreases from SF1 to SF9. This result demonstrates that temperature is a less selective factor than light in the study area. Species with strict oceanic requirements (value 1) have not been found in any plot, but are were plenty of oceanic and sub-oceanic spe- cies (values 2, 3, and 4). Continental or subcontinental species are very few, as well as continental-insensitive species. This confirms that the climate is oceanic according to the Rivas-Martínez (2005) bioclimatic classification system, and this could be the most determinant factor in species selection. Both drought-adapted (values 1, 2, 3) and moisture-demanding species (values 8 to 12) are absent in all plots. In most plots, species living primarily on moist to humid soils (values 5-6) have been recorded. The low frequency of moisture-indifferent species indicates that moisture has been a key factor in the species selection process. Species living in acid soil conditions (values 1,2 , and 3) are rare or absent apart from SF5. Subacid soil species (values 5-6) and low acid soil species (value 7) are quite common. The frequency of species indifferent to soil reaction is very high, demonstrating that this factor has little influence on species trends. Results show also that species present are characteristic of soils rich in nitrogen.

According to the Jacquard index, all of the plots are rather dissimilar. In fact, the value is always below 0.5 , with the exception of the comparison between plots SF6 and SF9 (0.57). This result indicates that different stand structures correspond to different floristic compositions on the ground floor.

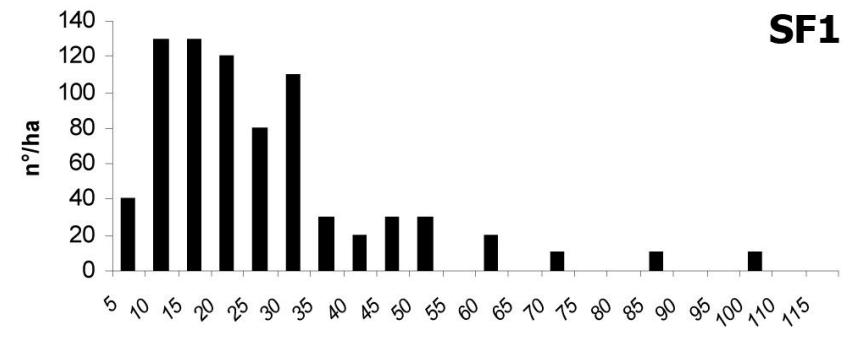

DBH

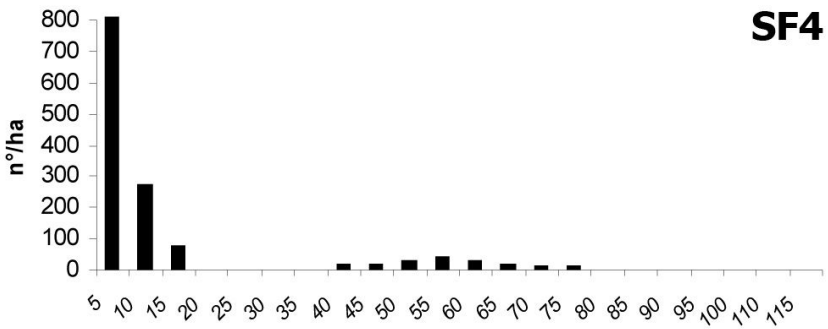

DBH

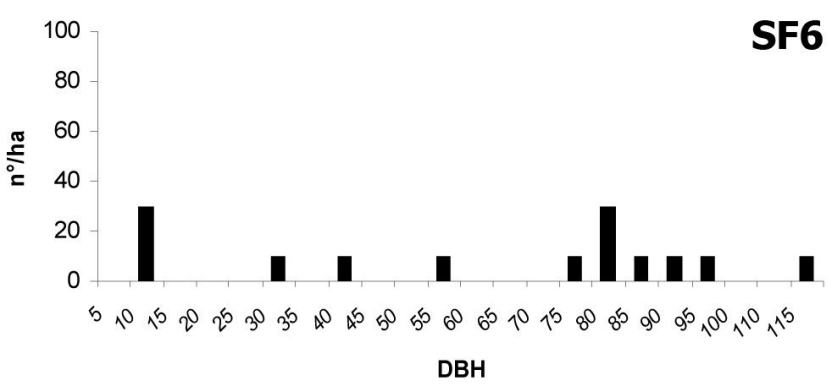

SF3

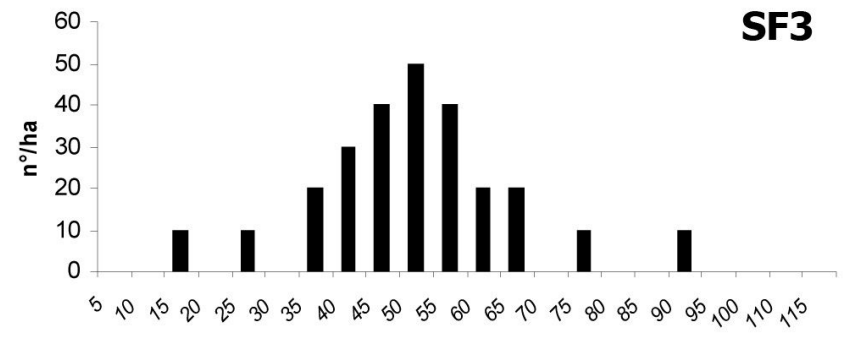

DBH

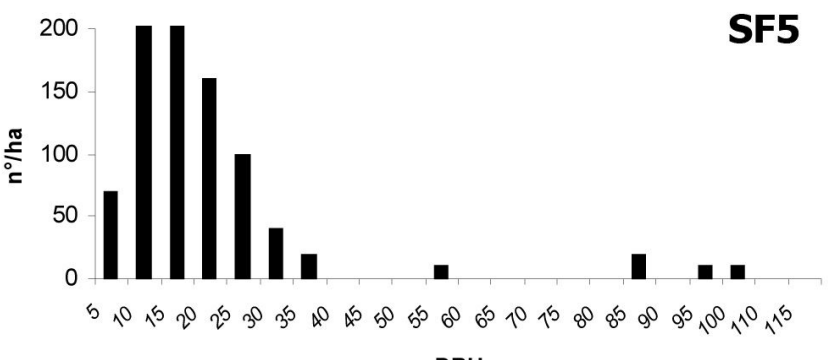

DBH

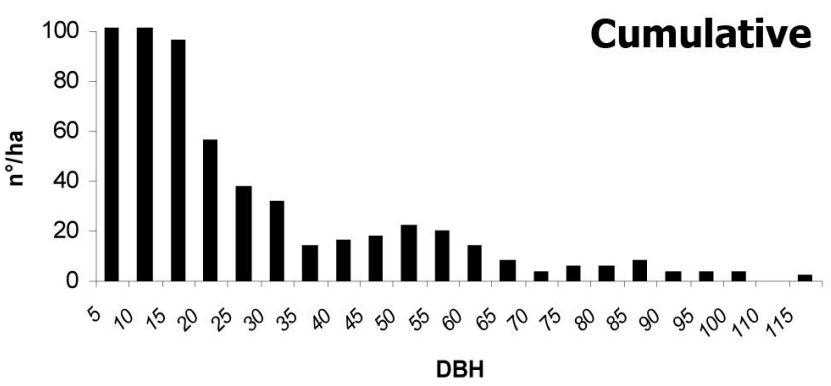

Fig. 1 - Diameter distribution, separately for each plot and cumulative. 
Tab. 3 - Values for the form parameter $C$ of the Weibull function applied, separately for plots and total.

\begin{tabular}{cc}
\hline ADS & C \\
\hline SF1 & 1.5 \\
SF3 & 1.4 \\
SF4 & 0.8 \\
SF5 & 1.2 \\
SF8 & 2.1 \\
Overall & 0.9 \\
\hline
\end{tabular}

\section{Dendrometric and structural aspects}

In Tab. 2 and Fig. 1, the dendrometric characteristics of all the plots are summarized.

SF1 is located in proximity of the forest ridge (1480 $\mathrm{m}$ a.s.l.) on a slope facing northeast. The slope average is $70 \%$ with peaks over $100 \%$. The forest profile is doublelayered and is composed of 770 trees per hectare with a $50.5 \mathrm{~m}^{2}$ basal area. The upper layer $(18 \mathrm{~m}<24 \mathrm{~m})$ is characterized by almost continuous cover. In term of individuals, beech is over $70 \%$ of the species present, mostly from gamic origin $(70 \%)$, while the remaining is composed of tree stump shoots $(30 \%)$. The other tree species are sycamores, equally subdivided between plants from gamic origin and tree stump suckers. The lower layer $(\mathrm{H}<10 \mathrm{~m})$ presents a discontinuous cover, not exceeding $30 \%$; beech is the dominant species, with sycamore contributing $15 \%$ of the individuals. In both cases, most of the individuals are originated from seed. The diameter distribution is represented by two parallel distribution curves, each resemble to the even-aged type. One results from the plants occupying the lower layer (diameter of the first three classes ranging from 5 to $25 \mathrm{~cm}$ ) and the other includes the mature trees of the upper layer (diameter from 35 to $95 \mathrm{~cm}$ ).

$\mathrm{SF} 3$ is located about $50 \mathrm{~m}$ below SF1, completely facing northeast, though the slope is smoother and never exceeds $50 \%$. The stand profile is single-layered (20-28 $\mathrm{m})$, characterized by full tree cover: the tree density is 360 beech per hectare, the basal area is $50.5 \mathrm{~m}^{2}$. The specific composition is dominated by beech, while sycamore is fairly sporadic and distributed as single trees or in small groups (2-3 individuals). Few beech individuals (2-10 $\mathrm{m})$ under canopy cover are

Tab. 5 - Comparison between layers as for the number of individuals in each plot (Chisquare test, d.f. $=26) .\left({ }^{*}\right)$ : $p<0.05$

\begin{tabular}{cc}
\hline Plot & Value \\
\hline SF1 & 10.77 \\
SF3 & 9.44 \\
SF4 & $16.28^{*}$ \\
SF5 & $15.67^{*}$ \\
SF8 & 0.44 \\
\hline
\end{tabular}

present and those few individuals are irregularly distributed. The diameter distribution is similar to an even-aged forest curve with modal and median values coinciding in class $45 \mathrm{~cm}$.

SF4 is located just below SF3 with similar slope conditions. The physiognomy is also similar, although in this case the forest profile is double-layered and composed of 1370 trees per hectare, with $42.9 \mathrm{~m}^{2}$ basal area. The upper layer $(20-30 \mathrm{~m})$ has almost complete canopy cover, with localized and small $\left(50-60 \mathrm{~m}^{2}\right)$ gaps. Beech is the dominant species of the stand $(90 \%$ of the individuals) with a few individual sycamores, placed in dominant or co-dominant positions. In the lower layer $(\mathrm{H}<8 \mathrm{~m})$, beech individuals from gamic origin are clumped in dense clusters. The trees of this layer show symptoms of shading disease: most of the plants have small diameters, besides the plagiotropic growth pattern of the main axis. The diameter distribution approximates an evenaged stand, modal class $45 \mathrm{~cm}$, with another peak in the first two diameter classes because of the presence of the natural regeneration.

SF5 is located at an altitude of $1300 \mathrm{~m}$ a.s.l. on an east-facing slope. The forest profile is double-layered, despite a tendency to being multi-layered in some locations. Some

a few sparse silver fir trees (H 12-15 m), occurs mainly close to the gap edges. Individuals of this species are also present at the floor level (H 2-5 m). On the whole, canopy cover is low. The distribution of diameter classes is almost even-aged (modal class 75 $\mathrm{cm}$ ), although the presence of silver fir in the lower layers creates an asymmetry to the left side of the distribution curve.

Comparing the diameter distribution of the five plots by the KS test, very significant differences emerge $(p<0.01)$. C values of the Weibull function are quoted in Tab. 3. In $\mathrm{SF} 4$, this parameter is 0.8 , and showing a reversed J curve. The values are $1.2,1.4,1.5$ and 2.1 respectively for SF5, SF3, SF1 and SF8, representing a positively-skewed, mound-shaped function. By joining data from all of the plots, the $\mathrm{C}$ parameter is 0.9 , indicating a reversed $\mathrm{J}$ diameter curve.

The Chi-square indicates a distribution of non-homogeneous individuals in the three layers among the five plots $\left(\chi^{2}{ }_{[8]}=143.6\right.$, $\mathrm{p}<0.01)$. The values of the $\chi^{2}$ test are reported in Tab. 4 in a pairwise comparison matrix. The results indicate very significant differences $(p<0.01)$, excluding pairing SF1 to SF3 and SF3 to SF8. The same test, performed within each plot (Tab. 5), indicates significant differences $(p<0.05)$ in SF4 and in SF5.

Tab. 4 - Pairwise-comparison between layers as for the number of individuals in each plot (Chi-square test, d.f. $=2$ ). $(* *): p<0.01$.

\begin{tabular}{cccccc}
\hline ADS & SF1 & SF3 & SF4 & SF5 & SF8 \\
\hline SF1 & - & 3.35 & $53.39^{* *}$ & $13.94^{* *}$ & $10.45^{* *}$ \\
SF3 & 3.35 & - & $25.36^{* *}$ & $17.4^{* *}$ & 4.86 \\
SF4 & $53.39^{* *}$ & $25.36^{* *}$ & - & $59.05^{* *}$ & $36.79^{* *}$ \\
SF5 & $13.94^{* *}$ & $17.4^{* *}$ & $59.05^{* *}$ & - & $32.08^{* *}$ \\
SF8 & $10.45^{* *}$ & 4.86 & $36.79^{* *}$ & $32.08^{* *}$ & - \\
\hline
\end{tabular}

910 beech trees per hectare with a $43.8 \mathrm{~m}^{2}$ of basal area have been recorded. Only beech $(25-32 \mathrm{~m})$ is present in the upper tree layer, and the canopy cover is irregular. The lower layer $(12-20 \mathrm{~m})$ is characterized only by beech, mostly from gamic origin. Sparse groups of small beeches $(2-5 \mathrm{~m})$ are not enough to constitute a definite layer. All of the individuals present in the lower layer show vigorous aspect. Diameter distribution tends to an uneven-aged stand, because of the simultaneous presence of a regeneration layer (5 to $15 \mathrm{~cm}$ diametric classes) and mature trees of the upper layer (last four diameter classes).

SF8 is located at an altitude of $1100 \mathrm{~m}$, facing east on level ground. The forest profile is mono-layered (38-44 $\mathrm{m}$ ) and the canopy cover is complete. There are 140 trees per hectare, with a basal area of $50.3 \mathrm{~m}^{2}$. A discontinuous intermediate layer, composed of

\section{The regeneration layer}

The results, listed separately for each plot, can be summarized as follows:

- SF1, 4833 saplings per hectare $(65 \%$ sycamore, $34 \%$ beech, $1 \%$ European elm) with an average height of $6.5 \mathrm{~cm}( \pm 2.0 \mathrm{SD})$

- SF3, 2233 saplings per hectare (58\% sycamore, $40 \%$ beech, $2 \%$ silver fir) with an average height of $5.9 \mathrm{~cm}( \pm 1.7 \mathrm{SD})$

- SF4, 19400 saplings per hectare $(51 \%$ beech, $48 \%$ sycamore, $1 \%$ ash) with an average height of $6.3 \mathrm{~cm}( \pm 2.1 \mathrm{SD})$

- SF5, 18567 saplings per hectare $(70 \%$ beech, $28 \%$ sycamore, $2 \%$ silver fir, ash, lime and common laburnum) with an average height of $6.7 \mathrm{~cm}( \pm 2.8 \mathrm{SD})$

- SF8, 11767 saplings per hectare $(66 \%$ silver fir, $24 \%$ sycamore, $8 \%$ beech, $2 \%$ ash and lime) with an average height of $4.4 \mathrm{~cm}$ $( \pm 1.9 \mathrm{SD})$

In terms of saplings number, ANOVA 
Tab. 6 - One way ANOVA for the variable average number of saplings for each sub-plot $\left(60 \mathrm{~m}^{2}\right)$. Variation source: plots.

\begin{tabular}{lcccc}
\hline Origin & d.f. & Variance & F & p-level \\
\hline $\begin{array}{l}\text { Between } \\
\text { plots }\end{array}$ & 4 & 10918.64 & 1.54253 & $\mathrm{p}<0.01$ \\
Error & 20 & 707.84 & - & - \\
\hline
\end{tabular}

Tab. 7 - Duncan's post-hoc comparison for the variable average number of saplings for each sub-plot $\left(60 \mathrm{~m}^{2}\right)$. Variation source: plots.

\begin{tabular}{ccc}
\hline Plot & $\begin{array}{c}\text { Average } \\
\left(\mathbf{n} / \mathbf{6 0} \mathbf{~ m}^{\mathbf{2}}\right)\end{array}$ & $\begin{array}{c}\text { Homogeneous } \\
\text { groups }\end{array}$ \\
\hline SF3 & 13 & $\mathrm{a}$ \\
SF1 & 29 & $\mathrm{a}$ \\
SF8 & 71 & $\mathrm{~b}$ \\
SF5 & 111 & $\mathrm{c}$ \\
SF4 & 116 & $\mathrm{c}$ \\
\hline
\end{tabular}

Tab. 8 - One way ANOVA for the variable average relative irradiance for each plot. Variation source: plots.

\begin{tabular}{lcccc}
\hline Origin & d.f. & Variance & F & p-level \\
\hline $\begin{array}{l}\text { Between } \\
\text { plots }\end{array}$ & 4 & 0.016553 & 12.5361 & $\mathrm{p}<0.01$ \\
Error & 780 & 0.00132 & - & - \\
\hline
\end{tabular}

Tab. 9 - Duncan's post hoc comparison for the variable average relative irradiance for each plot. Variation source: plots.

\begin{tabular}{ccc}
\hline Plot & $\begin{array}{c}\text { Average } \\
\text { I.R. }\end{array}$ & $\begin{array}{c}\text { Homogeneous } \\
\text { groups }\end{array}$ \\
\hline SF4 & $0.9 \%$ & $\mathrm{a}$ \\
SF3 & $1.5 \%$ & $\mathrm{a}$ \\
SF5 & $1.7 \%$ & $\mathrm{ab}$ \\
SF8 & $2.4 \%$ & $\mathrm{~b}$ \\
SF1 & $3.8 \%$ & $\mathrm{c}$ \\
\hline
\end{tabular}

(Tab. 6) shows very significant differences among the plots $(\mathrm{p}<0.01)$. The Duncan test (Tab. 7) highlights that the higher average values have been found in SF5 and in SF4 (111 and 116, respectively), and the lowest ones in SF3 and in SF1 (13 and 29, respectively), while SF8 average values (71) are intermediate, although rather distinct from the other plots.

Comparing the average values of $\mathrm{HS}$, ANOVA does not indicate significant differences among plots, mainly due to the strong variability within each plot. A tendency of progressive increase of the middle value of HS with decreasing altitude have been observed (Fig. 2).

Solar radiation at forest floor level

Considering the average value of I.R., ANOVA shows highly significant differ-

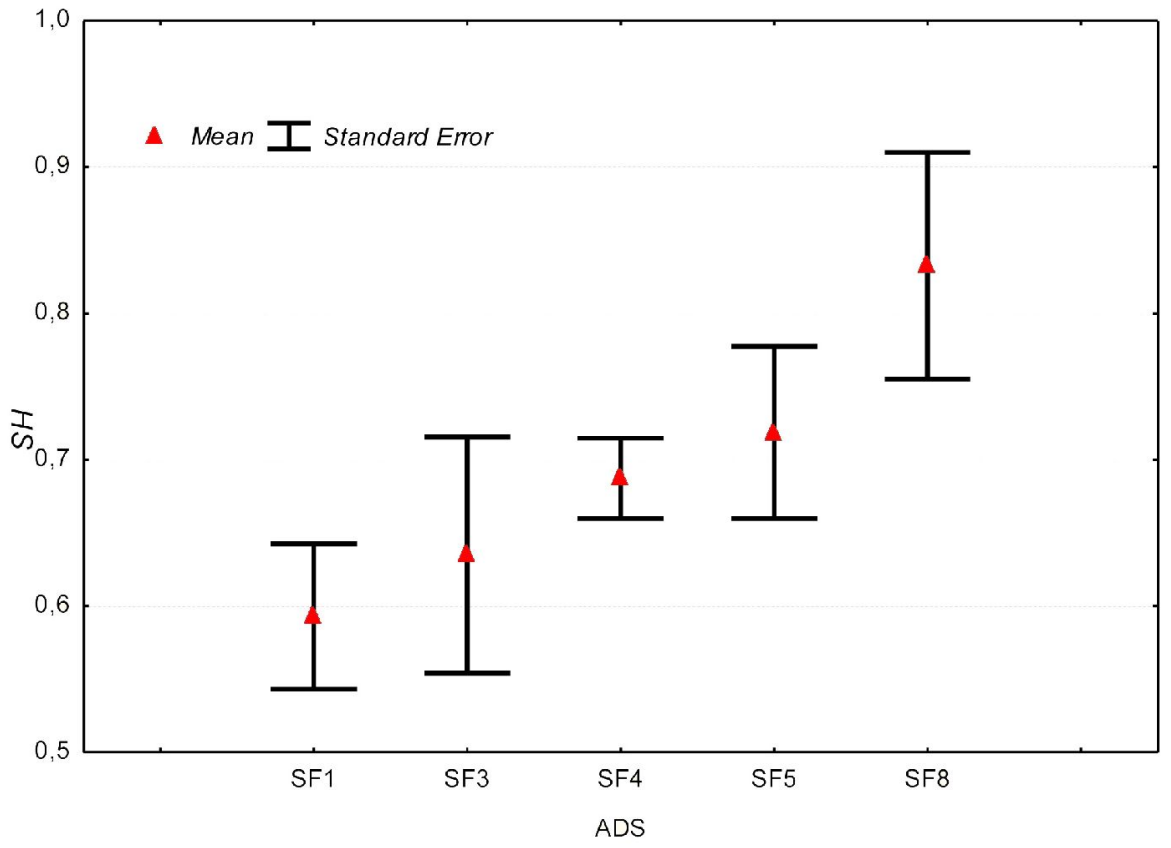

Fig. 2 - Variation of average HS values in each plot.

ences $(p<0.01)$ among the plots (Tab. 8). The lowest I.R. values have been found in SF4 and in SF3 (0.9 and 1.5\%, respectively), the highest in SF1 (3.8\%), and the intermediate values belong to SF5 and SF8 (1.7 and $2.4 \%$, respectively - Tab. 9). Light quantity at ground level does not seem to be related to seedling abundance and diversity.

\section{Discussion}

Despite the steep slopes and the uneven morphology, the RNI forests were harvested in the past, as indicated by the numerous charcoal areas located throughout the Reserve. The last harvests were seventy years ago, and even if it is not possible to accurately identify the areas where fellings occurred, harvests were probably located only in the most accessible zones considering the small amount of timber that was removed. This could have influenced the large amount of diversity in the spatial structure of the stands (Nardi Berti 1972, Paci \& Salbitano 1998).

Composition, development (in terms of both height and density) and distribution of the lower vegetation layers (especially in terms of natural regeneration of saplings) have been determined by site characteristics (especially altitude and soil fertility), past fellings, and the spontaneous occurrence of gaps.

Floristic samples show a considerable lack of species in the study area. In the RNI, Hofmann (1965) observed 160 species (91 included in the researcher's original samples) and, in a recent in-depth study, Gonnelli et al. (2009) reported 377 species. These data are consistent with the literature in regards to the low number of species belonging to the vascular flora within mature beech stands (Pignatti 1998).

Specific composition plays a key role in the understanding of forest ecosystem dynamics; however, according to Tilman (1999), it is crucial to consider the other components of diversity as well including, above all, the structural components. The occurrence of structurally complex forest stands increases along a gradient of slope, towards progressively steeper sites. The phenomenon can be explained, in part, by different intensity of harvesting events (Lindenmayer et al. 1999). Our results indicate roughly simplified structures, especially near the mountain ridge; this could be the result of a series of more or less concomitant causes:

- coppicing, which lasted longer on the ridges than in other areas of the forest, due to easier exploitation along the ridge;

- wind influence;

- combined influence of snow and wind, which could have caused more extended windbreakages in comparison to more protected sites.

Concerning altitude, we observed an increase both of site index (dominant height) and species diversity in the regeneration layer, moving from higher $(1500 \mathrm{~m})$ to lower $(900 \mathrm{~m})$ altitudes. Indeed, as altitude decreased, the increase in tree height was attributable, as well as bioclimatic factors, to the site morphology: the sites where the slope is more moderate, and which are characterized by deeper soils, were more frequent at lower altitudes. This can also help to explain the lower tree species diversity in 
the regeneration layer of the higher altitude areas, even if the effect of more selective climatic conditions (shorter vegetative season, more frequent frosts, stronger wind, and more persistent snow) can emphasize this phenomenon. It is also necessary to consider the influence of soil depth on the crown reaction to gap opening: more fertile areas induce a more vigorous reaction and, consequently, faster canopy closure.

Simplified (single-layer) stand structures are more frequent where canopy gaps are absent. Two-layered structures are the result of the occurrence of canopy gaps, which allow the settlement, and subsequently the establishment, of a lower regeneration layer. Where the gap dimensions allow canopy closure, this kind of structure persists. When the gaps are quite large, the regeneration layer reaches the top layer and the structure stand tends, once more, toward a single-layer. Multilayer structures are extremely rare at plot level and become evident only at a larger scale (mosaic of stand structures).

Our surveys indicate a high variability of tree diameter distribution patterns in the forest stands, especially in relation to the observed spatial structures. Such variability could be strictly related to the heterogeneity of site characteristics as well as to the effects of disturbance factors (both natural and anthropic). A study completed in southeastern Europe (Westphal et al. 2006) confirms that the reverse $\mathbf{J}$ curve is not the only pattern suitable to describe, at a level of detail, the diameter distributions in virgin and old-growth beech forests due to an underestimation of the intermediate diameter classes. Actually, combining the data of all the plots, the resulting distribution pattern is clearly attributable to the "reverse J-shaped curve", a pattern usually observed in natural stands developed without large scale disturbances (Motta et al. 2008)

Our observations, therefore, show that the dynamics of forest vegetation in the RNI is mostly affected by the interruption of tree canopy continuity. This implies substantial local variations of PAR in space and in time, which determine favourable ecological conditions for: (a) survival and growth of beech seedlings, or release of advanced beech regeneration; and (b) release of advanced silver fir regeneration.

Beech, the dominant species in both the regeneration and stand layers, more frequently regenerates according to an aggregated spatial distribution, each group corresponding to canopy cover openings originated from the collapse of one or a few individuals of the upper layer, a pattern recently highlighted in research carried out in old-growth Fagus-Abies forests in Slovenia (Nagel et al. 2006). However, depending on the canopy height and on the topography, light may penetrate close to the gap edge (Canham
1988). A similar successional trend has been described for the southcentral European virgin forests, where gap size is generally less than $400 \mathrm{~m}^{2}$, and large scale disturbances, related to gaps large over $1000 \mathrm{~m}^{2}$, are rather less frequent (Peterken 1996, Westphal et al. 2006). Also in the Suserup Skov old growth forest (Denmark), it has been observed that beech regeneration is favoured by openings originated by small scale disturbances (Emborg 1998, Emborg et al. 2000, Ritter et al. 2005 ), according to RI values $>3-4 \%$. From a practical forestry point of view, this can be considered the lower limit for the natural regeneration of this species (Burschel \& Huss 1964, Madsen 1995).

In some cases, according to our data, an important role can be played by advanced regeneration. Although beech saplings can survive under a locally closed canopy, their establishment is hindered by strong competition for light and other resources due to a dense cover of saplings and/or trees. By contrast, the release of beech "advanced regeneration" is favoured by gap occurrence (Wohlgemuth \& Wüthrich 2002, Nagel et al. 2006). As regards the natural regeneration of beech, the occurrence of canopy openings should be considered critical more in relation to the release of submitted advance regeneration than to the settlement of saplings (Madsen \& Hahn 2008).

Fir, more shade tolerant than beech, regenerates mainly in locations and conditions where the broadleaf saplings cannot survive for lack of light. The chances of regeneration of silver fir are indeed connected to: (1) settlement and initial growth under canopy cover at RI levels of $2-3 \%$ (a nearly exclusive niche); and (2) the subsequent occurrence of a gap, i.e., characteristics ecologically suitable for the release of advance regeneration. Silver fir, in fact, is less competitive when PAR availability is high enough to foster the natural regeneration of competitive species (Grassi \& Bagnaresi 2001). For instance, in the Apennine forests in Calabria (southern Italy), the settlement of silver fir natural regeneration has been recorded both under canopy cover and in small gaps (200-300 $\mathrm{m}^{2}$ ), especially corresponding to centralsouthern aspects, where beech regeneration is unfavoured (Albanesi et al. 2005).

By contrast, our data have shown that, in the Sasso Fratino Reserve, under a dense canopy cover, PAR values at the forest floor are, on average, too low to allow an effective process of natural regeneration, even for shade tolerant species such as silver fir or beech: the recorded values under the continuous canopy cover were in general below $2 \%$ of RI, the minimum threshold for the survival of silver fir saplings (Magini 1967, Hunziker \& Brang 2005). It follows that, in these conditions, the occurrence of small gaps is a necessary prerequisite for the initial phases of natural regeneration.

As a whole, natural regeneration of shade tolerant tree species like beech and silver fir (the most abundant in the mountain belt of the RNI) is favoured by the opening of relatively small canopy gaps (Whitmore 1989, Emborg 1998, Kneeshaw \& Prévost 2007), the most frequent type in the Sasso Fratino forest.

Light is not the only factor affecting silver fir regeneration in the Reserve. It has been observed that silver fir regeneration in central European mixed-beech forests occurs on a small scale, characterized by sparse aggregates. This pattern is not necessarily based on the relation to the degree of canopy cover (light availability), but also to the edaphic variability (the chance of regeneration success of silver fir in open sites of Sasso Fratino is favoured in presence of oligotrophic soils - Paci \& Salbitano 1998.) or to an interaction of other factors, not always identified (Nagel et al. 2006, Paluch 2005). Therefore, the considerable site variability in the Reserve of Sasso Fratino also plays a crucial role in the distribution of the species in the regeneration layer. Moreover, the natural regeneration of silver fir is also affected by the proportion of fir seed bearer trees in the stand surrounding the gap, as observed for mixed silver fir stands of central Europe (Dobrowolska 1998, Dobrowolska \& Veblen 2008).

\section{Conclusions}

The basis of close-to-nature silviculture, commonly accepted as a correct approach for sustainable forest management (Emborg 1998, Gamborg \& Larsen 2003), is the study of the relationships between the dynamics, both in space and time, of the forest stand structure and the vegetation dynamics (i.e., the successional processes) under the canopy cover. In forest stands, the patterns of spatial occupation by the trees determine, under the canopy cover, ecological conditions that influence the natural regeneration patterns (Jaehne \& Dohrenbusch 1997, Lindenmayer et al. 1999). Both the intensity and the frequency of the disturbance factors, from natural or anthropic origin, are the basis of the evolutionary dynamics of forest stands and, therefore, of their structural heterogeneity. Similarly, silviculture influences the forest dynamics through modifications of the stands in terms of structure and species composition (Oliver \& Larson 1996, Bagnaresi et al. 2002).

In particular, gap dynamics - with particular regard to aspect, slope, dimension, and canopy closure time - significantly contribute to understanding the role of small scale disturbances in the forest systems (Canham 1988, Coates \& Burton 1997, Emborg et al. 2000). Silvicultural spin-offs are evident on account of the evidence that gaps can be 
opened artificially.

The near natural forest of Sasso Fratino represents a basic reference for nature-based silviculture of beech and mixed beech forests in the Apennines. According to this work, as well as to other studies in near-natural temperate mixed forests of the mountain belt, the evolutionary trend is not homogeneous.

From this point of view, it has been ascertained that, at present, the forest is going through the dynamic "understorey reinitiation stage" (Oliver \& Larson 1996), which is more or less advanced, and after canopy openings due to the collapsing of one or a few trees in the upper layer, a quick and localized settlement of natural regeneration has been observed. The following development leads, in the absence of anthropic activities, to the gradual transition of these stands to the stage of old-growth forests.

This phenomenon, which occurs heterogeneously in the RNI, causes a progressive increase in structural complexity, as it was recently described for the Douglas fir forests in Oregon (Zenner 2004). From this point of view, it is necessary to point out that small scale environmental heterogeneity, as a result of structural complexity, favours the conservation of species diversity in the forest (Peterson et al. 1990, Nagel et al. 2006).

Natural beech-silver fir mixed forests often tend to structural uniformity, at least for a large part of the forests of middle European mountain belt: the phenomenon is related to the capacity of the trees to accumulate biomass. A consequence is the closure of the canopy cover (occurring in different timelapses, depending on the situation), mainly in the case of forests characterized by competitive tree species such as beech (Schütz 2002). Structural irregularity at a small scale, conversely, is not the rule in near-natural forests, with the exception of some phases (especially the degradation one) characterizing the old growth or virgin forests cycle Actually, in mixed woods, the different cycle length of the tree species can lead to a structural differentiation, even if plenter-like structures are only occasionally reported, more often under the $15 \%$ of the forests total surface (Mayer et al. 1980, in Schütz 2002).

As for management aspects of the Apennine silver fir-beech mixed forests located in the middle-mountain belt, according to the results of the present research, shelterwood uniform systems or gap systems covering large patches $\left(>1000 \mathrm{~m}^{2}\right)$ are not suitable for stands similar to the ones described in the RNI. In the first case, the light microclimate at the forest floor would be altered in favour of beech, in the latter case more light-demanding tree species (mainly Acer pseudoplatanus), grasses and shrubs would invade the gaps hindering the natural regeneration both of beech and silver fir. In any case, such successional patterns would hamper the establishment of silver fir regeneration. In contrast, the opening of gaps between 300 and $600 \mathrm{~m}^{2}$ may represent a point of reference for a nature-based silviculture aimed at preserving the species composition (Paci \& Salbitano 1998). In order to achieve this goal, the dimension as well as the position of the gaps should be carefully calibrated, taking into account the tree species to be favoured. In this sense, gap exposure and slope, as well as the height of the trees surrounding the gap, will be considered and the largest gaps will favour beech regeneration. With the goal of conservation of tree species diversity, an irregular shelterwood felling (interpreted as an arrangement between selection and shelterwood cuttings) could be recommended as well (Diaci 2006). Periodical monitoring of RNI will allow the investigation of the evolutionary trends of the forest stands: thus, it will be possible to assess the reliability of the hypotheses expressed.

\section{References}

A.A.V.V. (1999). Ecologia strutturale e funzionale di faggete italiane (Scarascia Mugnozza G ed). Edagricole Calderini, Bologna (Italy).

A.A.V.V. (2004). Standard di buona gestione per i boschi Appenninici e Mediterranei (SAM). (Marchetti M ed). Accademia Italiana Scienze Forestali. [online] URL: http://www.aisf.it

Albanesi E, Gugliotta OI, Mercurio I, Mercurio R (2005). Effects of gap size and within-gap position on seedlings establishment in silver fir stands. iForest 1 (1): 55-59. - doi: 10.3832/ ifor0448-0010055

Bagnaresi U, Giannini R, Grassi G, Minotta G, Paffetti D, Pini Prato E, Proietti Placidi AM (2002). Stand structure and biodiversity in mixed, uneven-aged coniferous forests in the eastern Alps. Forestry 75 (4): 357-364. - doi: 10.1093/forestry/75.4.357

Bailey L, Dell R (1973). Quantifying diameter distributions with the weibull function. Forest Science 19 (2): 97-104.

Bottacci A (2009). Aspetti storici. La riserva naturale integrale di Sasso Fratino 1959-2009: 50 anni di conservazione della biodiversità (Bottacci A ed). Corpo Forestale dello Stato-Ministero delle Politiche Agricole Alimentari e Forestali. Arti grafiche Cianferoni, Stia, AR (Italy), pp. 29-38.

Braun-Blanquet J (1932). Plant sociology. Mc Graw-Hill Book Comp., New York and London. Burschel P, Huss J (1964). Die reaktion von Buchensämlingen auf beschattung. Forstarchiv 35 (11): 225-233.

Canham CD (1988). Growth and canopy architecture of shade-tolerant trees: response to canopy gaps. Ecology 69 (3): 786-795. - doi: 10.2307/ 1941027

Coates KD, Burton PJ (1997). A gap-based approach for development of silvicultural systems to address ecosystem management objectives.
Forest Ecology and Management 99: 337-354. doi: 10.1016/S0378-1127(97)00113-8

Diaci J (2006). Nature-based silviculture in Slovenia: origins, development and future trends. Nature-based forestry in central Europe - Alternatives to industrial forestry and strict preservation. In: "Nature-based forestry in central Europe, alternatives to industrial forestry and strict preservation" (Diaci J ed). Studia For. Slov. 126: 119-131.

Dobrowolska D (1998). Structure of silver fir (Abies alba Mill.) natural regeneration in the "Jata" reserve in Poland. Forest Ecology and Management 110: 237-247. - doi: 10.1016/ S0378-1127(98)00286-2

Dobrowolska D, Veblen TT (2008). Treefall-gap structure and regeneration in mixed Abies alba stands in central Poland. Forest Ecology and Management 255: 3469-3476. - doi: 10.1016/j. foreco.2008.02.02

Ellenberg H (1988). Vegetation ecology of central Europe. Cambridge University Press, Cambridge, UK.

Emborg J (1998). Understory light conditions and regeneration with respect to the structural dynamics of a near-natural temperate deciduous forest in Denmark. Forest Ecology and Management 106: 83-95. - doi: 10.1016/S0378-1127 (97)00299-5

Emborg J, Christensen M, Heilmann-Clausen J (2000). The structural dynamics of Suserup Skov, a near-natural temperate deciduous forest in Denmark. Forest Ecology and Management 126: 173-189. - doi: 10.1016/S0378-1127 (99)00094-8

Gabbrielli A (1978). L'opera rinnovatrice di Carlo Siemoni selvicoltore Granducale. Ann. Acc. It. Sci. For. 27: 173-194

Gabbrielli A, Sottesoldi E (1977). La storia della Foresta Casentinesi nelle carte dell'Archivio dell'Opera del Duomo di Firenze dal secolo XIV al XIX. Collana Verde $n^{\circ} 43$, MAF, Rome, Italy. Gamborg C, Larsen JB (2003). "Back to nature" a sustainable future for forestry? Forest Ecology and Management 179: 559-571. - doi: 10.1016/ S0378-1127(02)00553-4

Gonnelli V, Bottacci A, Zoccola A (2009). Secondo contributo alla conoscenza della flora della Riserva Naturale Integrale di Sasso Fratino (Parco Nazionale delle Foreste Casentinesi, Monte Falterona e Campigna). In: "La Riserva Naturale Integrale di Sasso Fratino: 1959-2009. 50 anni di conservazione della biodiversità" (Bottacci A ed). Corpo Forestale dello Stato, Ufficio Territoriale per la Biodiversità di Pratovecchio, Arezzo, Italy, pp. 75-118.

Grassi G, Bagnaresi U (2001). Foliar morphological and physiological plasticity in Picea abies and Abies alba saplings along a natural light gradient. Tree Physiology 21: 959-967. - doi: 10.1093/treephys/21.12-13.959

Hofmann A (1965). L'abieti-faggeto di Sasso Fratino ed i suoi aspetti fitosociologici. Tipografia Valbonesi, Forlì, Italy. Archivio botanico e biogeografico italiano XLI (4): 1-15.

Hunziker U, Brang P (2005). Microsite patterns of 
conifer seedling establishment and growth in a mixed stand in the southern Alps. Forest Ecology and Management 210: 67-79. - doi: 10.1016/j. foreco.2005.02.019

INFC (2008). Le stime di superficie 2005 - Prima parte. Inventario nazionale delle foreste e dei serbatoi forestali di carbonio (Tabacchi G, De Natale F, Di Cosmo L, Floris A, Gagliano C, Gasparini P, Genchi L, Scrinzi G, Tosi V eds). MiPAF, Corpo Forestale dello Stato, Ispettorato Generale, CRA - ISAFA, Trento. [online] URL: http://www.infc.it/

Jaehne S, Dohrenbusch A (1997). Ein Verfahren zur Beurteilung der Bestandesdiversität. Forstw. Cbl. 116: 333-345. - doi: 10.1007/BF02766909

Kneeshaw DD, Prévost M (2007). Natural canopy gap disturbances and their role in maintaining mixed-species forests of central Quebec, Canada. Canadian Journal of Forest Research 37 (9): 1534-1544. - doi: 10.1139/X07-112

Koop H (1989). Forest dynamics. SILVI-STAR: a comprehensive monitoring system. Springer, Berlin, Germany.

Leibundgut H (1982). Europaeische Urwaelder der Bergstufe. Haupt, Bern, Switzerland.

Lindenmayer DB, Mackey BG, Mullen IC., Mc Carthy MA, Gill AM, Cunningham RB, Donnelly CF (1999). Factors affecting stand structure in forests - are there climatic and topographic determinants? Forest Ecology and Management 123: 55-63. - doi: 10.1016/S0378-1127(99) 00018-3

Madsen P (1995). Effects of soil water content, fertilization, light, weed competition and seedbed type on natural regeneration of beech (Fagus sylvatica). Forest Ecology and Management 72 : 251-264. - doi: 10.1016/0378-1127(95)97453-Y Madsen P, Hahn K (2008). Natural regeneration in a beech-dominated forest managed by closeto-nature principles - a gap cutting based experiment. Canadian Journal of Forest Research 38 (7): 1716-1729. - doi: 10.1139/X08-026

Magini E (1967). Ricerche sui fattori della rinnovazione naturale dell'abete bianco sull'Appennino. L'Italia Forestale e Montana XXII (6): 261270.

Motta R, Maunaga Z, Berretti R, Castagneri D, Lingua E, Meloni F (2008). La Riserva forestale di Lom (Repubblica di Bosnia Erzegovina): descrizione, caratteristiche, struttura di un popolamento vetusto e confronto con popolamenti stramaturi delle Alpi italiane. Forest@ 5 100-111 - doi: 10.3832/efor0512-0050100

Nagel TA, Svoboda M, Diaci J (2006). Regeneration patterns after intermediate wind disturbance in an old-growth Fagus-Abies forest in southeastern Slovenia. Forest Ecology and Management 226: 268-278. - doi: 10.1016/j.foreco.2006.
01.039

Nardi Berti R (1972). Prime indagini sulle caratteristiche dei soprassuoli della riserva naturale integrale di Sasso Fratino. L'Italia Forestale e Montana XXVII:156-165

Oldeman RA (1990). Forests: elements of silvology. Springer-Verlag, Berlin, Germany.

Oliver CD, Larson BC (1996). Forest Stand Dynamics. John Wiley \& Sons, New York, NY, USA

Ozenda P (1985). La vegetation de la Chaine Alpine. Masson, Paris, France.

Paci M, Salbitano F (1998). The role of studies on vegetation dynamics in undisturbed natural reserves towards the need of knowledge for closeto-nature silvicultural treatments: the case-study of Natural Reserve of Sasso Fratino (Foreste Casentinesi, northern-central Apennines). AISFEFI International Conference on "Forest management in designated conservation and recreation areas" (Morandini R, Merlo M, Paivinnen R eds). Florence (Italy) 7-11 October 1998. University of Padua Press, pp. 145-156.

Padula M (1983). Storia delle foreste demaniali casentinesi nell'Appennino tosco-romagnolo. Collana Verde $n^{\circ} 63$. M.A.F., C.F.S. ex ASFD, Rome, Italy.

Paluch J (2005). The influence of the spacial pattern of trees on forest floor vegetation and silver fir (Abies alba Mill.) regeneration in uneven-aged forests. Forest Ecology and Management 205: 283-298. - doi: 10.1016/j.foreco.2004. 10.010

Peterken GF (1996). Natural Woodland. Cambridge University Press, Cambridge, UK.

Peterson CJ, Carson WP, McCarthy BC, Pickett STA (1990). Microsite variation and soil dynamics within newly created treefall pits and mounds. Oikos 58: 39-46. - doi: 10.2307/ 3565358

Pignatti S (1976). Geobotanica. In: "Trattato di botanica" (Cappelletti C ed). UTET, Turin, Italy, pp. 801-997.

Pignatti S (1982). Flora d'Italia. Voll. 3. Edagricole, Bologna, Italy.

Pignatti S (1998). I Boschi d'Italia. UTET, Turin, Italy.

Raunkiaer C (1934). The life forms of plants and statistical plant geography. Clarendon, Oxford, UK

Ritter E, Dalsgaard L, Einhorn KS (2005). Light, temperature and soil moisture regimes following gap formation in a semi-natural beech-dominated forest in Denmark. Forest Ecology and Management 206: 15-33. - doi: 10.1016/j.foreco. 2004.08.011

Rivas-Martínez S (2005). Worldwide bioclimatic classification system phytosociological research center. [online] URL: http://www.globalbioclimatics.org/

Sanesi G (1962). Osservazioni sulle caratteristiche e l'evoluzione dei suoli della Foresta di Campigna (Forli). Relazioni con la vegetazione forestale. Annali Accademia Italiana Scienze Forestali XI: 97-137.

Schütz JP (2002). Silvicultural tools to develop irregular and diverse foest structures. Forestry 75 (4): 329-336 - doi: 10.1093/forestry/75.4.329

Schütz JP (2006). Opportunities and strategies of biorationalisation of forest tending within nature-based management. Nature-based forestry in Central Europe: alternatives to industrial forestry and strict preservation (Diaci $\mathrm{J}$ ed). Ljubljana (Slovenia). [online] URL: http://www. bf.uni-lj.si/gozdarstvo/oddelek/katedre/goj_gozd/ objave/Nature-based forestry in CE.pdf

Tilman D (1999). The ecological consequences of changes in biodiversity: a search for general principles. Ecology 80: 1455-1474. - doi: 10.1890/0012-9658(1999)080[1455:TECOCI]2. $0 . \mathrm{CO} ; 2]$

Townsend CR, Begon M, Harper J (2003). Essentials of ecology $\left(2^{\text {nd }}\right.$ edn.). Blackwell Publishing Company, UK.

Westphal C, Tremer N, von Oheimb G, Hansen J, von Gadow K, Härdtle W (2006). Is the reverse J-shaped diameter distribution universally applicable in European virgin beech forests? Forest Ecology and Management 223: 75-83. - doi: 10.1016/j.foreco.2005.10.057

Whitmore TC (1989). Canopy gaps and the two major groups of forest trees. Ecology 70 (3): 536-538. - doi: 10.2307/1940195

Wohlgemuth T, Wüthrich HK (2002). Disturbance of microsites and early tree regeneration after windthrow in Swiss mountain forests due to the winter storm Vivian 1990. For. Snow Landsc. Res. 77: 17-47.

Zenner EK (2004). Does old-growth condition imply high live-tree structural complexity? Forest Ecology and Management 195: 243-258. - doi: 10.1016/S0378-1127(04)00222-1

\section{Supplementary Material}

Appendix 1 - Floristic list, separately for plot, with abundance/dominance indexes according to Braun-Blanquet (1932) scale, modified by Pignatti (1976): (5) cover $80 \div 100 \%$; (4) cover $60 \div 80 \%$; (3) cover $40 \div 60 \%$; (2) cover $20 \div 40 \%$; (1) well represented species, cover from $1 \%$ to $20 \% ;(+)$ species present, but scarce cover $(<1 \%)$; (r): sporadic species (1-5 individuals).

Link: Bianchi_564@suppl001.pdf 